\title{
Effect of RU 486 on luteal function in the early pregnant rat*
}

\author{
T. Kawano, H. Okamura, C. Tajima, K. Fukuma and H. Katabuchi \\ Department of Obstetrics and Gynaecology, Kumamoto University Medical School, Kumamoto 860, \\ Japan
}

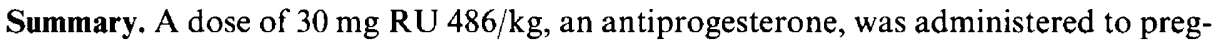
nant rats on Day 2 (Group 1) or Day 4 (Group 2) of pregnancy. RU 486 significantly changed serum progesterone and oestradiol concentrations and luteal $3 \beta$-HSD and $20 \alpha$-HSD activities in Group 1, and implantation was significantly inhibited. The luteal $3 \beta$-HSD activity in Group 2 rats on Day 6 was significantly $(P<0.01)$ lower than the control value $(7.5 \pm 0.6$ and $10.1 \pm 0.6 \mathrm{mU} / \mathrm{mg}$ protein respectively). This decline in the $3 \beta$-HSD activity was followed by a marked decrease in the serum progesterone concentration, resulting in a significant decrease of the progesterone/oestradiol ratio and implantation was completely inhibited. The $20 \alpha$-HSD activity, which could not be detected on Day 6 in the control rats, was twice as great in Group 2 than in Group 1 rats $(17.5 \pm 1.2$ and $7.4 \pm 3.1 \mathrm{mU} / \mathrm{mg}$ protein respectively). Ultrastructural examination of corpora lutea of Group 2 rats confirmed luteolysis. These results suggest that RU 486 has a luteolytic effect and its anti-implantation effect is concomitant with luteolysis of the corpora lutea of pregnancy.
\end{abstract}

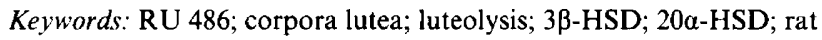

\section{Introduction}

RU 486 [17 $\beta$-hydroxy-11 $\beta$-(4-dimethylaminophenyl)-17 $\alpha$-(1-propynyl) oestra-4,9-dien-3-one] is a synthetic steroid which binds to endometrial progesterone receptors and acts as a progesterone antagonist (Healy et al., 1983; Gravanis et al., 1985). It has been shown that RU 486 prevents implantation in rats, and Philibert et al. (1985) reported that implantation was inhibited when a single dose ( 30 or $100 \mathrm{mg} / \mathrm{kg}$ ) of RU 486 was administered on any day between Days 2 and 6 after mating. However, the question of whether the anti-implantation effect of RU 486 is mediated by the changes in ovarian steroid hormones has not been studied.

Dimattina et al. (1986) observed that RU 486 induced a significant decrease in the activity of $3 \beta$ hydroxysteroid dehydrogenase ( $3 \beta$-HSD) concomitant with a decrease in progesterone secretion by

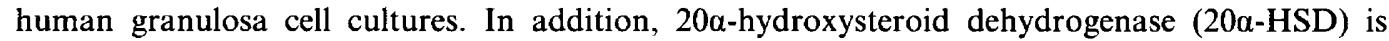
known to regulate the secretion of progesterone from corpora lutea (Kuhn \& Briley, 1970), and a marked increase in activity has been observed in regressing corpora lutea (CL) of pregnant rats treated with abortifacient agents (Okazaki et al., 1976).

To elucidate the effect of RU 486 on luteal function, a dose capable of inhibiting implantation was given to pregnant rats on Days 2 or 4 after mating, and the number of implantation sites, serum progesterone and oestradiol concentrations, and luteal $3 \beta-\mathrm{HSD}$ and $20 \alpha-\mathrm{HSD}$ activities were examined. Morphological characteristics of $\mathrm{CL}$ were also investigated.

*Reprint requests to Dr H. Okamura. 


\section{Materials and Methods}

Animals. Female Wistar strain rats, 10 weeks old, were kept in an air-conditioned room at $23^{\circ} \mathrm{C}$ with $12 \mathrm{~h}$ of artificial light and $12 \mathrm{~h}$ of darkness daily, with free access to pelleted food and water. They were paired with mature male rats, and vaginal smears were examined to confirm impregnation. Day I of pregnancy was the day when spermatozoa were found in the vaginal smears. In Exp. I, the animals were injected subcutaneously with $30 \mathrm{mg}$ RU $486 / \mathrm{kg}$ body weight (Roussel-Uclaf, Romainville, France), dissolved in 70\% ethanol (20 mg/ml) on Day 2 (Group 1) or Day 4 (Group 2), and killed on Day 6 to count the number of implantation sites. At autopsy, blood samples were obtained from the posterior vena cava to assay serum progesterone and oestradiol concentrations. CL were enucleated from the excised ovaries to measure $3 \beta$-HSD and $20 \alpha$-HSD activities. Parts of the CL were processed for electron microscopy. Rats injected with ethanol alone on Day 2 or 4 were assigned to the control group. In a preliminary investigation, a solvent of $70 \%$ ethanol had no effect on luteal function of early pregnant rats. In Exp. II, rats were treated with RU 486 as in Exp. I but were killed on Day 1, 2, 3, 4, 5 or 6 to investigate the effects of RU 486 on $3 \beta$-HSD and $20 \alpha$-HSD in CL.

Hormone assays. All blood samples were left at room temperature for $30 \mathrm{~min}$. Serum was separated from blood and stored at $-20^{\circ} \mathrm{C}$ until the assay for progesterone and oestradiol-17 $\beta$ by radioimmunoassay kits obtained from International CIS (Sorin Biomedica, Saluggia, Italy). The sensitivities of the assay were $0 \cdot 10 \mathrm{ng} / \mathrm{ml}$ for progesterone and $10 \mathrm{pg} / \mathrm{ml}$ for oestradiol. The cross-reactivities of the progesterone antiserum were as follows: progesterone, $100 \%$; corticosterone, $2 \cdot 5 \%$; deoxycorticosterone, $2.5 \%$; 17-hydroxyprogesterone, $2.0 \%$; cortexolone, $0.25 \%$; testosterone, $0.2 \%$; pregnenolone, $0 \cdot 16 \% ; 20$-dihydroprogesterone, $0 \cdot 16 \%$; cortisone, $0 \cdot 12 \%$; androstenedione; $0 \cdot 1 \%$; cholesterol, cortisol, dehydroepiandrosterone, oestradiol, oestriol, oestrone, etiocholanolone, $0 \cdot 05 \%$. The cross-reactivities of the oestradiol antiserum were as follows: oestradiol, $100 \%$; oestrone, $0 \cdot 7 \%$; oestriol, $0.55 \%$; 20-dihydroprogestererone, $0.007 \%$; cortisol, cortisone, cortexolone, corticosterone, cholesterol, progesterone, 17-hydroxyprogesterone, etiocholanolone, pregnenolone, androstenedione, testosterone, dehydroepiandrosterone, deoxycorticosterone, $0.002 \%$. The intra-assay variations were $7.6 \%$ for progesterone and $3.4 \%$ for oestradiol. The interassay variations were $8.5 \%$ and $9.0 \%$ respectively. All samples were assayed in duplicate.

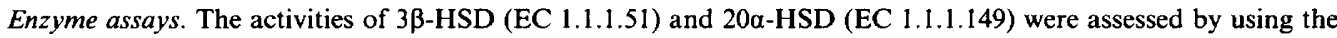
methods reported by Kuhn \& Briley (1970) and Okazaki et al. (1976) with a slight modification. CL were weighed and homogenized in $0.25 \mathrm{M}$-sucrose at $0^{\circ} \mathrm{C}$ in a glass homogenizer at a concentration of $10 \mathrm{mg}$ wet weight $/ \mathrm{ml}$. The homogenate was centrifuged for $60 \mathrm{~min}$ at $105000 \mathrm{~g}$. The supernatant was used for the assay of 20a-HSD activity. The precipitate was rehomogenized in the concentration stated above and centrifuged at $800 \mathrm{~g}$ for 5 min. The supernatant was used for the assay of $3 \beta-\mathrm{HSD}$ activity. The assay mixture of $3 \beta-\mathrm{HSD}$ contained $40 \mu \mathrm{mol}$ glycine $-\mathrm{NaOH}$ (pH 9.4), $0.9 \mathrm{mg}$ bovine serum albumin, $0.5 \mu \mathrm{mol}$ oxidized nicotinamide adenine dinucleotide (NAD ${ }^{+}$) and enzyme solution $(0.05 \mathrm{ml})$. That of $20 \mathrm{a}$-HSD contained $50 \mu \mathrm{mol}$ Tris $-\mathrm{HCl}(\mathrm{pH} 7.5), 0.9 \mathrm{mg}$ bovine serum albumin, $0.5 \mu \mathrm{mol}$ oxidized nicotinamide adenine dinucleotide phosphate $\left(\mathrm{NADP}^{+}\right)$, and enzyme solution $(0.05 \mathrm{ml})$. The assay mixtures were preincubated for $5 \mathrm{~min}$ at $37^{\circ} \mathrm{C}$, and the reaction was started by the addition of the respective $3 \beta-\mathrm{HSD}$ or $20 \alpha-\mathrm{HSD}$ substrates in a final volume of $0.80 \mathrm{ml}$. The substrate for $3 \beta$-HSD was $0.005 \mathrm{mg}$ pregnenolone $(0.1 \mathrm{mg} / \mathrm{ml}$ in ethanol). That for $20 \alpha$-HSD was $0.015 \mathrm{mg} 20 \alpha$-hydroxypregn-4-en-3-one $(0.5 \mathrm{mg} / \mathrm{ml}$ in ethanol). The $3 \beta$-HSD or $20 \alpha$-HSD activities were assayed spectrophotometrically dependent on the increase in NADH or NADPH absorbance at $340 \mathrm{~nm}$ respectively, and expressed as munits $/ \mathrm{mg}$ protein. The amount of enzyme producing $1 \mu \mathrm{mol} \mathrm{NADH}$ or NADPH was defined as 1 unit of enzyme activity. The method of Lowry et al. (1951) was used for the protein determination using bovine serum albumin as the standard.

Electron microscopic examination. For electron microscopy, the tissue specimens of corpora lutea were cut into small pieces, which were fixed in a chilled $2.5 \%$ glutaraldehyde in $0.1 \mathrm{M}$-cacodylate buffer (pH 7.4 ) and post-fixed in $1 \%$ osmic acid. Dehydration, embedding and $1 \mu \mathrm{m}$ sectioning were performed as routine procedures, and ultrathin sections were stained with uranyl acetate and lead citrate, and were examined with an Hitachi $\mathbf{H}-300$ electron microscope.

Statistical analysis. Statistical evaluations of the results were done with unpaired Student's $t$ tests or with Tukey's tests for multiple comparison. The threshold of significance was set at $P=0.05$.

\section{Results}

\section{Implantation sites}

As shown in Table 1, there were very few implantation sites in Group 1 and none in Group 2 rats treated with RU 486 .

\section{Ovarian steroid hormones}

As shown in Table 1, progesterone and oestradiol concentrations in Group 1 rats on Day 4 differed from those of the control rats and progesterone values in Group 2 rats on Day 6 were lower 
Table 1. Effect of RU 486 on the number of implantation sites and serum concentrations of ovarian steroid hormones examined on Days 4 and 6 of pregnancy in rats

\begin{tabular}{|c|c|c|c|c|c|}
\hline \multirow[b]{3}{*}{ No. of implantation sites } & \multicolumn{2}{|c|}{ Control group } & \multicolumn{2}{|c|}{ Group 1} & \multirow{2}{*}{$\frac{\text { Group } 2}{\text { Day } 6}$} \\
\hline & Day 4 & Day 6 & Day 4 & Day 6 & \\
\hline & & $11 \cdot 2 \pm 0.4$ & & $1 \cdot 4 \underset{(14)}{ \pm} 0 \cdot 6^{* *}$ & $\begin{array}{c}0^{* *} \\
(23)\end{array}$ \\
\hline Progesterone conc. $(\mathrm{ng} / \mathrm{ml})$ & $47 \cdot 0 \underset{(4)}{ \pm} 2 \cdot 2$ & $69 \cdot 7 \underset{(7)}{ \pm} 10 \cdot 3$ & $27 \cdot 2 \underset{(5)}{ \pm} 8 \cdot 4^{*}$ & $52.9 \pm 10.9$ & $38 \cdot 3+9 \cdot 6$ \\
\hline Oestradiol conc. $(\mathrm{pg} / \mathrm{ml})$ & $17 \cdot 5 \underset{(4)}{ \pm 1 \cdot 2}$ & $22 \cdot 3 \underset{(7)}{ \pm} 2 \cdot 3$ & $29.8 \underset{(5)}{ \pm} 3 \cdot 8^{*}$ & $26 \cdot 0 \pm \frac{173}{(7)}$ & $35 \cdot 5 \pm \frac{ \pm 8 \cdot 4}{(8)}$ \\
\hline $\begin{array}{l}\text { Progesterone/oestradiol ratio } \\
\qquad\left(\times 10^{3}\right)\end{array}$ & $2 \cdot 73 \pm 0.24$ & $3.41 \underset{(7)}{ \pm} 0.75$ & $1 \cdot 04 \pm 0.37^{*}$ & $1.72 \pm \frac{ \pm}{(7)} 0.33$ & $1 \cdot 35 \pm 0.33^{* *}$ \\
\hline
\end{tabular}

Values are mean \pm s.e.m. for the no. of animals in parentheses.

$* P<0.05$ compared with control value on Day 4 .

$* * P<0.01$ compared with control value on Day 6 .

Table 2. Effect of RU 486 on enzyme activity in rat corpora lutea on Day 6 of pregnancy

\begin{tabular}{|c|c|c|}
\hline & $\begin{array}{l}\text { 33-HSD activity } \\
\text { (mU/mg protein) }\end{array}$ & 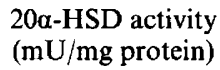 \\
\hline Control group & $\begin{array}{c}10 \cdot 1 \pm 0 \cdot 6 \\
(11)\end{array}$ & $\begin{array}{c}0 \\
(11)\end{array}$ \\
\hline Group 1 & $9 \cdot 8 \pm 1.0$ & $7 \cdot 4 \pm 3 \cdot 1^{*}$ \\
\hline Group 2 & $7 \cdot 5 \pm 0.6^{*}$ & $17 \cdot 5 \underset{(5)}{ \pm} 1.2^{*+}$ \\
\hline
\end{tabular}

Values are mean \pm s.e.m. for the no. of animals in parentheses.

${ }^{*} P<0.01$ compared with control value.

$\dagger P<0.01$ compared with Group 1 value.

than those in controls $(P<0.05$, unpaired Student's $t$ test $)$. The progesterone/oestradiol ratio calculated from the progesterone and oestradiol values of the respective rats was lower than that of controls in all experimental animals.

\section{Steroid converting enzyme activities on Day 6}

The activity of $3 \beta$-HSD was significantly lower than that of the control rats in Group 2 rats (Table 2). There was no detectable activity of $20 \alpha$-HSD in the controls, but values in Group 2 rats were twice as great as those in Group 1 rats (Table 2).

\section{Daily activities of steroid-converting enzymes}

As shown in Fig. 1(a), 3 $\beta$-HSD activity rose gradually from Day 1 to 6 in the control group. In Group 1, 3 $\beta$-HSD activity declined at Day 3, and then was as high as in the controls on Day 4, 5 

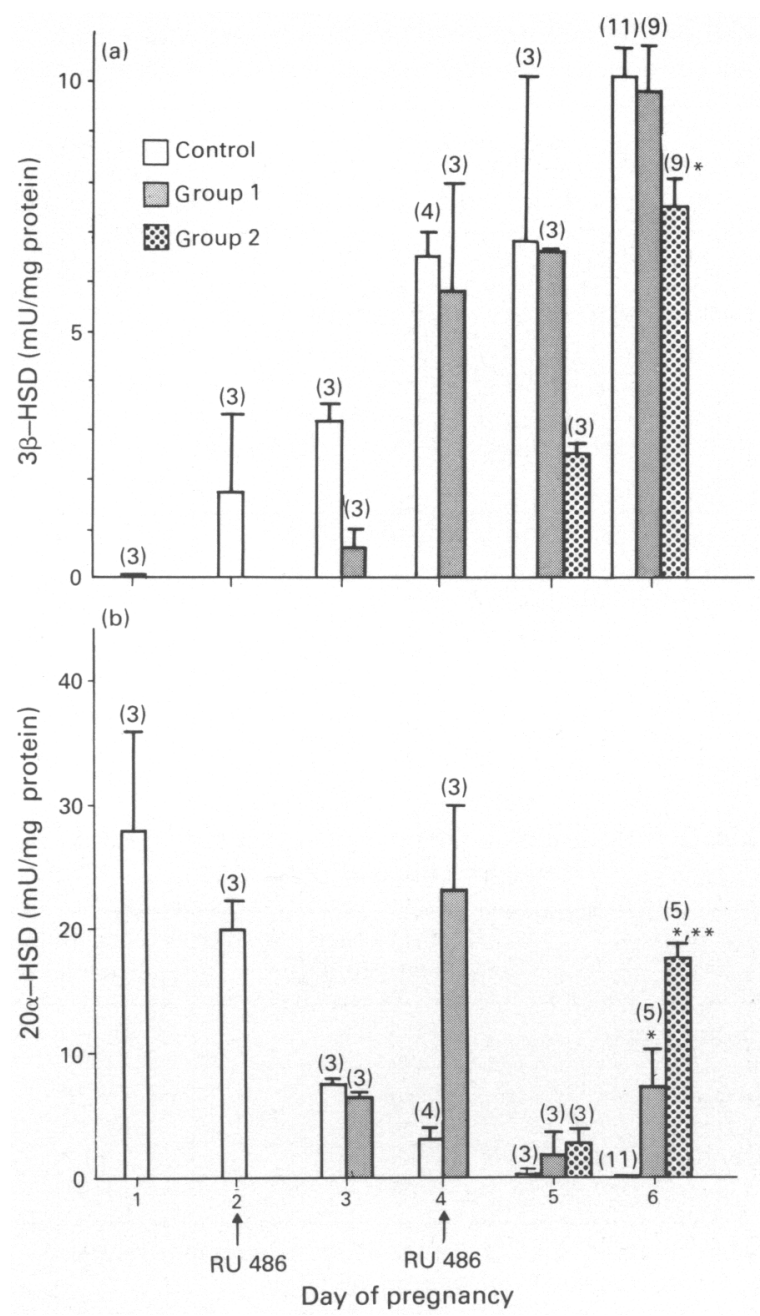

Fig. 1. Daily changes in the activities of (a) 3 $\beta$-HSD and (b) 20 $\alpha$-HSD in control rats, and rats in Group 1 and 2 . Values are mean \pm s.e.m. for the no. of animals in parentheses. $+P<0 \cdot 05$ compared with control value on Day $3 ;{ }^{*} P<0.01$ compared with control value on Day 6; ${ }^{* *} P<0.01$ compared with Group 1 value on Day 6.

and 6. In Group 2, values were lower on Day 5, but increased by Day 6, albeit to values lower than in the control group. In contrast, $20 \alpha$-HSD activity declined from Day 1 to 6 in the control group, but increased at Days 4 and Day 6 in Group 1 and 2 respectively (Fig. 1b).

\section{Electron microscopic examination}

In Group 2 rats the spaces between luteal cells were wider in Group 2 rats than in controls (Figs 2a \& 2c). Lipid droplets in the cytoplasm of the control luteal cells were uniform in size and had a high electron density (Fig. 2a). In contrast, those in the cytoplasm of Group $2 \mathrm{CL}$ were of various sizes with vacuoles and relatively low electron density (Fig. 2c). The nuclei of the control luteal cells were round and well-expanded (Fig. 2a), while those of Group 2 rats were irregularly shaped 

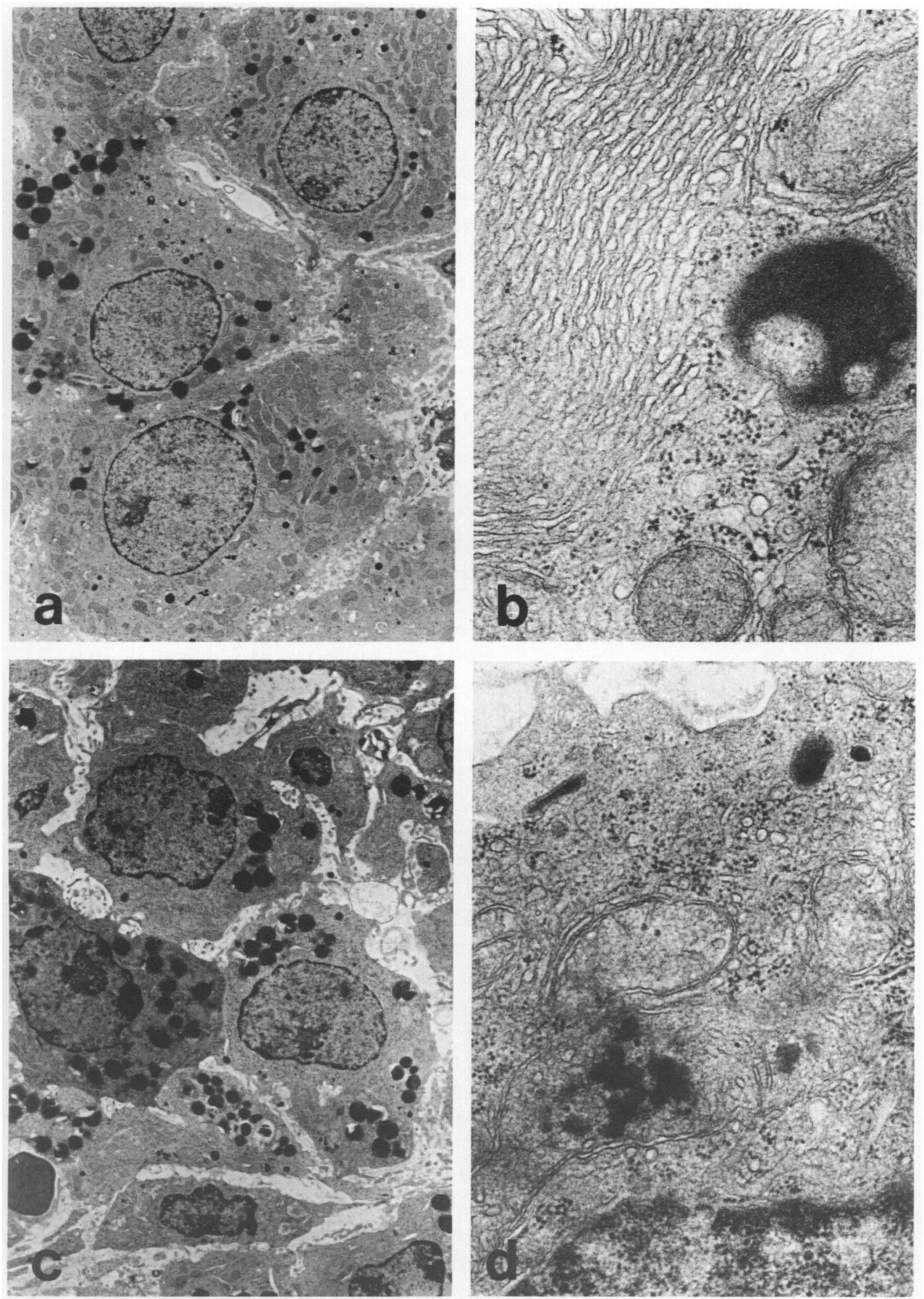

Fig. 2. Electron micrographs of corpora lutea on Day 6 of pregnancy from a control rat ((a) $\times 2200$; (b) $\times 34000)$ and a Group 2 rat $((\mathrm{c}) \times 2600$; (d) $\times 28000)$. 
(Fig. 2c). Smooth endoplasmic reticulum (SER) and the mitochondria of the control luteal cells were well-developed and abundant (Fig. 2b). In comparison, the SER was sparse, and elongated mitochondria were observed in Group $2 \mathrm{CL}$. Some mitochondria contained small granules with high electron density (Fig. 2d).

\section{Discussion}

In the present study, a dose of $30 \mathrm{mg}$ RU $486 / \mathrm{kg}$ exerted an anti-implantation effect in both experimental groups. This result is in agreement with the report of Philibert et al. (1985). The effect was more marked in Group 2 than in Group 1. RU 486 presumably acts directly on the endometrium, thus inhibiting implantation. Since there was a significant decrease in progesterone concentration on Day 4 in Group 1, it is assumed that this decreased progesterone is responsible for the unsuitable development of the endometrium. The normality of the progesterone concentration in Group 1 on Day 6 suggests that the impairment of corpora lutea by RU 486 administered on Day 2 was temporary and that the function was fully recovered by Day 6. This speculation was supported by the fact that luteal $3 \beta-H S D$ and $20 \alpha-H S D$ activities returned to the control level after their initial changes. The present results showed that the serum concentration of oestradiol changed significantly in Group 1 on Day 4. This raised serum oestradiol concentration may have nothing to do with RU 486 inhibiting implantation (Psychoyos \& Prapas, 1987). As reported by Gidley-Baird et al. (1986), the progesterone/ oestradiol ratio showed more significant changes than did progesterone alone, thus indicating its role as a better predictor of implantation failure than the absolute concentrations of either ovarian hormone.

The present result showed a significant decrease in the activity of the $3 \beta-\mathrm{HSD}$, which is responsible for the conversion of pregnenolone to progesterone, indicating that RU 486 decreases progesterone production by inhibiting the $3 \beta-\mathrm{HSD}$ activity in luteal cells. The suppression of $3 \beta$-HSD by RU 486 observed on Day 3 in Group 1 rats was temporary and was followed by a progressive increase in a manner similar to that in the control rats until Day 6, resulting in a serum progesterone concentration close to the control level on Day 6 in these rats.

The enzyme $20 \alpha$-HSD catabolizes progesterone to $20 \alpha$-hydroxypregn-4-en-3-one and serves as a marker of luteolysis (Pupkin et al., 1966; Lamprecht et al., 1969; Strauss \& Stambaugh, 1973). The

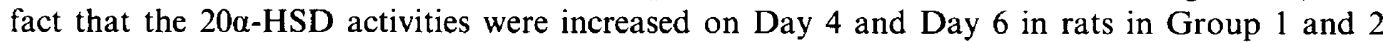
respectively indicates a luteolytic effect of RU 486 on the corpora lutea of pregnant rats. Unlike $3 \beta$-HSD, 20 $\alpha$-HSD showed the maximum changes 2 days after the drug injection. The subsequent decrease on Day 6 in Group 1 rats also reflects the recovery of the luteal cells.

To confirm the luteolytic changes indicated by the changes in serum progesterone concentration and luteal steroid dehydrogenase activities, the corpora lutea of rats in Group 2 were studied ultrastructurally. The morphological changes in these corpora lutea were characteristic for luteolysis, and consistent with the luteolytic findings observed in the corpus luteum of pregnant rats treated with abortifacient agents such as prostaglandin F-2 $\alpha$ or cyanoketone (Okamura et al., 1972; Okamura \& Yoshida, 1974).

The mechanism by which RU 486 causes luteolysis of early pregnant corpora lutea is suggested to be as follows; (1) it has a suppressive effect on the hypothalamo-pituitary axis causing decreased secretion of luteotrophic factors from the pituitary gland; (2) it has a direct chemical action on the luteal cells in pregnancy; and (3) it has antiprogestagenic activity at the level of the luteal cells. The last possibility is interesting in that lutein cells appear to need progesterone, their final product, to maintain their own cellular viability.

We thank Roussel-Uclaf for the gift of RU 486. 


\section{References}

Dimattina, M., Albertson, B., Seyler, D.E., Loriaux, D.L. \& Falk, R.J. (1986) Effect of the antiprogestin RU 486 on progesterone production by cultured human granulosa cells: inhibition of the ovarian $3 \beta$-hydroxysteroid dehydrogenase. Contraception 34, 199-206.

Gidley-Baird, A.A., O’Neill, C., Sinosich, M.J., Porter, R.N., Pike, I.L. \& Saunders, D.M. (1986) Failure of implantation in human in vitro fertilization and embryo transfer patients: the effect of altered progesterone/estrogen ratios in humans and mice. Fert. Steril. 45, 69-74.

Gravanis, A., Schaison, G., George, M., De Brux, J., Satyaswaroop, P.G., Baulieu, E.E. \& Robel, P. (1985) Endometrial and pituitary responses to the steroidal antiprogestin RU 486 in postmenopausal women. $J$. clin. Endocr. Metab. 60, 156-163.

Healy, D.J., Baulieu, E.E. \& Hodgen, G.D. (1983) Induction of menstruation by an antiprogesterone steroid (RU 486) in primates: site of action, dose-response relationships, and hormonal effects. Fert. Steril. 40, 253-257.

Kuhn, N.J. \& Briley, M.S. (1970) The roles of pregn-5ene-3 $\beta, 20 \alpha$-diol and $20 \alpha$-hydroxy steroid dehydrogenase in the control of progesterone synthesis preceding parturition and lactogenesis in the rat. Biochem. J. 117, 193-201.

Lamprecht, S.A., Lindner, H.R. \& Strauss, J.F., III (1969) Induction of $20 \alpha$-hydroxysteroid dehydrogenase in rat corpora lutea by pharmacological blockade of pituitary prolactin secretion. Biochim. Biophys. Acta 187, 133-143.

Lowry, O.H., Rosebrough, N.J., Farr, A.L. \& Randall, R.J. (1951) Protein measurement with the folin phenol reagent. J. biol. Chem. 193, 265-275.
Okamura, H. \& Yoshida, Y. (1974) The effect of cyanoketone on the corpus luteum of the pregnant rat. An ultrastructural study. Acta obstet. Gynaec. Jpn. 26, $113-116$.

Okamura, H., Yang, S-L., Wright, K.H. \& Wallach, E.E. (1972) The effect of prostaglandin $F_{2} \alpha$ on the corpus luteum of the pregnant rat. An ultrastructural study. Fert. Steril. 23, 475-483.

Okazaki, T., Okamura, H., Motohashi, T., Morikawa, H., Yogo, I. \& Nishimura, T. (1976) An enzymologic study of corpora lutea in early pregnant rats treated with abortifacient agents. Fert. Steril. 27, 980-986.

Philibert, D., Moguilewsky, M., Mary, I., Lecaque, D., Tournemine, C., Secchi, J. \& Deraedt, R. (1985) Pharmacological profile of RU 486 in animals. In The Antiprogesterone Steroid $R U 486$ and Human Fertility Control, pp. 49-68. Eds E. E. Baulieu \& S. J. Segal. Plenum Press, New York.

Psychoyos, A. \& Prapas, I. (1987) Inhibition of egg development and implantation in rats after postcoital administration of the progesterone antagonist RU 486. J. Reprod. Fert. 80, 487-491.

Pupkin, M., Bratt, H., Weisz, J., Lloyd, C.W. \& Balogh, K., Jr (1966) Dehydrogenases in the rat ovary. I. A histochemical study of $\Delta^{5}-3 \beta$ - and $20 \alpha$-hydroxysteroid dehydrogenases and enzymes of carbohydrate oxidation during the estrous cycle. Endocrinology 79, 316-327.

Strauss, J.F., III \& Stambaugh, R.L. (1973) Induction of $20 \alpha$-hydroxysteroid dehydrogenase in rat corpora lutea of pregnancy by prostaglandin $F_{2} \alpha$. Prostaglandins 5, 73-85.

Received 25 August 1987 